\title{
Vascular Leakage in Dengue Hemorrhagic Fever Is Associated with Dengue Infected Monocytes, Monocyte Activation/Exhaustion, and Cytokines Production
}

\author{
Sirichan Chunhakan, ${ }^{1}$ Punnee Butthep, ${ }^{1}$ Sutee Yoksan, ${ }^{2}$ \\ Kanchana Tangnararatchakit, ${ }^{3}$ and Ampaiwan Chuansumrit ${ }^{3}$ \\ ${ }^{1}$ Department of Pathology, Faculty of Medicine Ramathibodi Hospital, Mahidol University, Bangkok 10400, Thailand \\ ${ }^{2}$ Vaccine Development Center, Mahidol University, Salaya Campus, Nakhon Pathom, Thailand \\ ${ }^{3}$ Department of Pediatrics, Faculty of Medicine Ramathibodi Hospital, Mahidol University, Bangkok 10400, Thailand
}

Correspondence should be addressed to Punnee Butthep; punnee.but@mahidol.ac.th

Received 22 October 2014; Revised 6 January 2015; Accepted 11 January 2015

Academic Editor: Aaron S. Dumont

Copyright (C) 2015 Sirichan Chunhakan et al. This is an open access article distributed under the Creative Commons Attribution License, which permits unrestricted use, distribution, and reproduction in any medium, provided the original work is properly cited.

\begin{abstract}
The vascular leakage was shown by the increment of hematocrit (Hct), dengue viral infected monocyte, monocyte status, and cytokines production in patients infected with dengue virus. Dengue viral antigens were demonstrated in monocytes (CD14+) from peripheral blood mononuclear cells. The increased levels of Hct, interleukin- (IL-) 10, and tumor necrosis factor-alpha (TNF$\alpha$ ) were detected in dengue fever (DF), dengue hemorrhagic fever (DHF) and dengue shock syndrome (DSS) patients as compared with other febrile illnesses (OFIs). The highest levels of Hct and IL-10 were detected in DSS patients as compared with other groups $(P<0.05)$ especially on one day before and after defervescence. The unstimulated and lipopolysaccharide- (LPS- $)$ stimulated monocytes from DSS patients showed the significantly decreased of intracellular IL-1 $\beta$ and TNF- $\alpha$. In addition, the lowest level of mean fluorescence intensity (MFI) of CD11b expression on monocytes surface in DSS patients was also demonstrated. Furthermore, the negative correlations between IL-10 levels and intracellular IL-1 $\beta$ and MFI of CD11b expression in unstimulated and LPSstimulated monocytes were also detected. Nevertheless, not only were the relationships between the prominent IL-10 and the suppression of intracellular monocyte secretion, namely, IL-1 $\beta$, TNF- $\alpha$, demonstrated but also the effect of vascular leakage was observed.
\end{abstract}

\section{Introduction}

The complication of DHF/DSS is thought to result from a complex interplay between the virus, host genetics, and host immune factors also depending on individual, epidemiologic, and ecologic conditions $[1,2]$. Several studies reported that monocytes are natural host cells for dengue virus [3, 4]. Monocytes have been implicated in both pathogenesis and protection of dengue such as the production of interferon$\alpha$ in response to dengue virus [5]. On the other hand, monocytes promote dengue pathogenesis by being the primary vessel of virus propagation [6]. In addition, monocytes/macrophage can produce cytokines and chemokines that compromise the integrity of the endothelial cell layer [7-9], possibly leading to vascular leakage, the hallmark of severe dengue diseases $[10,11]$. Furthermore, monocytes are known to die spontaneously by apoptosis and this can be prevented by appropriate stimuli such as LPS, TNF- $\alpha$, and IL-1 $\beta[12,13]$. Dengue-infected monocytes could stimulate cytokines/chemokines production such as TNF- $\alpha$ and IL- $1 \beta$ which are known to activate vascular endothelial cells and lead to vascular leakage.

IL-10 is a major anti-inflammatory cytokine that has been associated with several diseases and is considered as an important immunoregulatory mediator produced by monocytes, dendritic cells, and T and B lymphocytes [14]. Recently, an elevated level of IL-10 has been reported in patients infected with dengue virus, especially in severe dengue infection $[15,16]$. Both TNF- $\alpha$ and IL-10 have been involved in the thrombocytopenia and hemorrhagic manifestation 
observed during dengue infection [17]. Previously, there are many studies which reported that IL-10 is critically involved in the genesis of DHF, an increase in IL-10 levels has been correlated with platelet decay in dengue infection, and IL-10 may be downregulating lymphocyte and platelet function [18-20]. In addition, IL-10 could be involved in the induction of $\mathrm{T}$ cell apoptosis described in the secondary virus infection [21]. The infected monocytes, or memory $\mathrm{T}$ cells activated by infected monocytes as antigen presenting cells, could be the main sources of IL-10 in dengue infections [22]. Recently, the detection of dengue viral antigen in peripheral blood mononuclear cells which can provide a rapid diagnosis of dengue virus infection and the alteration of cytokines and chemokines in the febrile episode which related to DSS patients were reported $[23,24]$. Therefore, the aims of this study are to demonstrate the hematological changes especially the increment of Hct which indicate the vascular leakage, dengue viral infected monocytes, and the monocyte's markers of activation/exhaustion as shown by the proinflammatory and anti-inflammatory cytokines production including of TNF- $\alpha$, IL- $1 \beta$, and IL-10 especially intracellular cytokines in monocytes of patients infected with dengue virus in order to understand the cause and effect relationship which may lead to the severity of the diseases.

\section{Materials and Methods}

2.1. Clinical Samples and Definitions. Thai children with suspected dengue virus infection admitted at the Department of Pediatrics, Faculty of Medicine Ramathibodi Hospital, Mahidol University, Bangkok, Thailand, were enrolled in this study. The subjects consisted of patients with DF, DHF grade I, DHF grade II, and DHF grades III and IV (DSS) [25]. Diagnosis of dengue infection was confirmed by viral isolation using virus inoculation technique [26] and/or presence in acute and convalescent sera of dengue-specific IgM [27] and IgG [28] determined by ELISA method. Other febrile illness (OFIs) patients, having no dengue virus-specific IgM and $\mathrm{IgG}$ responses and negative for isolated dengue virus, were included as controls. Ethical approval was obtained from the Committee on Human Rights Related to Researches involving Human Subjects of Faculty of Medicine Ramathibodi Hospital, Mahidol University, Bangkok, Thailand. Informed consent was obtained from parents or caregivers.

Day 0 was designated as day of defervescence, when temperature dropped below $37.5^{\circ} \mathrm{C}$ without a subsequent elevation. Days prior to defervescence were designated as Day -1 , Day -2 , and so on, and days after defervescence were designated as Day +1 , Day +2 , and so on. The complete blood count was performed in all samples using automated blood cell analyzer (Sysmex XE-5000, Sysmex, Japan).

2.2. Identification of Monocyte as a Target Cell of Dengue Virus Infection. The smear of peripheral blood mononuclear cells (PBMCs) was prepared by the technique as previously described [29]. The smear was doubled-stained with fluorescein isothiocyanate- (FITC-) conjugated polyvalent dengue 1-4 antisera [30] and R-phycoerythrin-cyanin 5.1- (PC5-) conjugated CD14 (Immunotech, Marseille, France), a specific molecule for monocyte population, and examined under a laser scanning confocal microscope: MRC-1024 (Bio-Rad, Hertfordshire, UK). Positive control consisted of monolayer LLC-MK2 cells infected with dengue virus type 2 (16681) strain and harvested on Day 7 (provided by Vaccine Development Center, Mahidol University) and negative control was provided by white blood cells with negative staining on the smear.

2.3. Determination of $I L-10, T N F-\alpha$, and $I L-1 \beta$. The plasma levels of interleukin-10, TNF- $\alpha$, and IL- $1 \beta$ in patients infected with dengue virus were determined by using the commercial cytokines and growth factors array I (Randox, London, UK). All samples were examined as undiluted plasma according to the manufacturer's protocol. The researchers who carried out the study were blind to the clinical status, results of viral isolation, and dengue-specific IgM and IgG.

2.4. Assessment of Monocyte Status Using Flow Cytometry. For intracellular cytokines determination, sodium heparinized blood was incubated with GolgiPlug: brefeldin A (BFA) (BD Biosciences, San Jose, USA) for 4 hours at $37^{\circ} \mathrm{C}$ in $5 \% \mathrm{CO}_{2}$ with and without $1 \mu \mathrm{g} / \mathrm{mL}$ lipopolysaccharide (LPS) (Sigma, St. Louis, USA). Unstimulated and LPS-stimulated blood samples were lysed with FACS Lysing solution (BD Biosciences, USA). After centrifuging and decanting the supernatant, WBC pellets were washed and stained with PC5-conjugated CD14 (Immunotech, Marseille, France) for 15 minutes and, after washing, the samples were incubated for 10 minutes with FACS permeabilizing solution (BD Biosciences, San Jose, USA) and incubated with FITCconjugated antihuman TNF- $\alpha$ (R\&D Systems, Minneapolis, USA) and phycoerythrin- (PE-) conjugated antihuman IL-1 $\beta$ (R\&D Systems, Minneapolis, USA) for 30 minutes in the dark at room temperature. Then, the stained cells were washed and resuspended in $1 \%$ paraformaldehyde.

For CD11b expression on the surface of monocytes, sodium heparinized blood was lysed with $4^{\circ} \mathrm{C}$ FACS lysing solution (BD Biosciences, San Jose, USA) for $10 \mathrm{~min}$ utes. After centrifugation and discarding the supernatant, the WBC pellets were washed and incubated with PC5conjugated CD14 and FITC-conjugated CD11b (Immunotech, Marseille, France) for 20 minutes at $4^{\circ} \mathrm{C}$ in the dark. The stained cells were washed and analyzed within 24 hours by FACSCalibur flow cytometer (BD Biosciences, San Jose, USA) and the isotype control antibodies (mouse IgGl conjugated with FITC and PE) (R\&D Systems, Minneapolis, USA) were used as the negative markers. The assessment of monocyte status was performed by gating on CD14-positive cells including percentage of CD14+ cells expressing TNF- $\alpha$ and IL- $1 \beta$ in both resting and activated stage for intracellular cytokines and mean fluorescence intensity (MFI) of monocyte (CD14+) with CD11b expression.

2.5. Statistical Analysis. The results were compared among the studied groups of patients infected with dengue virus based on clinical assessment (DF, DHF I, DHF II, and DSS) 
TABLE 1: Clinical diagnosis and demographic information of studied patients.

\begin{tabular}{lcccc}
\hline \multirow{2}{*}{ Diagnosis } & \multicolumn{3}{c}{ Number of patients } & Age (years) \\
& Total & Male & Female & Mean (range) \\
\hline Dengue fever & 36 & 16 & 20 & $10.5(4-14)$ \\
DHF grade I & 33 & 16 & 17 & $12.0(5-17)$ \\
DHF grade II & 27 & 12 & 15 & $12.3(7-15)$ \\
DSS & 11 & 5 & 6 & $8.9(4-15)$ \\
OFIs & 8 & 5 & 3 & $11.2(5-19)$ \\
\hline Total & 115 & 54 & 61 & $11.1(4-19)$ \\
\hline
\end{tabular}

DHF: dengue hemorrhagic fever; DSS: dengue shock syndrome; OFIs: other febrile illnesses.

and OFIs patients. The nonparametric Mann-Whitney $U$ test and the Kruskal-Wallis test were used to calculate statistical significance for the differences in markers of monocyte activation/exhaustion between groups of patients. Comparisons between results obtained at different time points were performed using the Wilcoxon signed rank test and to study the linear relationship between variables, Spearman's correlation coefficients were calculated. Differences were considered significant with $P<0.05$.

\section{Results}

3.1. Demographic Information and Hematological Determinations. Clinical diagnosis and demographic information are shown in Table 1 and the distribution of studied samples followed by the day of illness related to fever is shown in Table 2. The mean of maximum, minimum, and percentage of increment of Hct in patients with DF, DHF grades I and II, DSS, and other OFIs patients were shown in Table 3. The highest level of mean increment of Hct (\%) was detected in DSS patients. Mean \pm SD of platelet counts in DF, DHF grades I and II, DSS, and OFIs patients was shown in Table 4. The lowest platelet numbers were demonstrated in DSS patients on Day 0, and the thrombocytopenia was shown in other types of dengue-infected patients.

3.2. Identification of Dengue Viral Antigen in Peripheral Blood Monocytes. Dengue viral antigen found in PBMCs was demonstrated in CD14 positive cells or monocytes. The results of double stained detection were shown in Figure 1 as dengue viral antigen positive-stained cells in panel (a) and double-stained cells for dengue viral antigen and CD14 positive cells in panel (b).

\subsection{Plasma Levels of IL-10, TNF- $\alpha$, and IL-1 $\beta$}

3.3.1. Interleukin-10 (IL-10). The levels of IL-10 from Day -2 to Day +2 in all groups of patients were elevated as compared to the levels on the day of convalescence. The highest level was detected in DSS patients especially on Day -1 and Day $+1(P<$ $0.05)$, consequences were in DHF II, DHF I, and DF patients, and the lowest level was demonstrated in OFIs patients. On the day of convalescence, the levels of IL-10 in all groups were less than $1.5 \mathrm{pg} / \mathrm{mL}$ (Table 5).

3.3.2. Tumor Necrosis Factor- $\alpha$ (TNF- $\alpha)$. On the day of defervescence, the level of TNF- $\alpha$ in DSS patients was significantly lower than the levels in DF and DHF II $(P<0.05)$, whereas the highest level was shown in DSS patients on Day +1 . From Day -2 to Day +2 , the mean levels of TNF- $\alpha$ in all patients infected with dengue virus was significantly higher than that on convalescent day $(P<0.05)$ except in DHF I patients on Day +2 (Table 6).

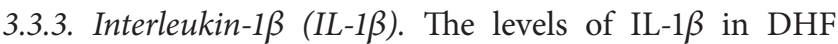
patients did not show the significant difference as compared to the levels on the day of convalescence. In contrast, the increased levels of IL- $1 \beta$ were detected in DF and OFIs patients from Day -1 to Day +2 as compared with the levels on the day of convalescence. From Day -1 to Day +2 , the mean levels of IL- $1 \beta$ in DF patients were higher than the other groups. In DSS patients, the mean levels of IL- $1 \beta$ on Day +1 and Day +2 were lower than those on convalescent day (Table 7).

3.4. Intracellular TNF- $\alpha$ and IL-1 $\beta$ Expression in Peripheral Blood Monocytes. Intracellular TNF- $\alpha$ and IL- $1 \beta$ expressions in peripheral blood monocytes (CD14+) were determined by flow cytometry and defined as monocyte activation (Figure 2). The percentage of intracellular IL-1 $\beta$ expression in DSS patients on Day 0 and Day +1 was significantly lower than in DF, DHF I, DHF II, and OFIs patients $(P<0.05)$ (Figure 2(a)). After LPS-stimulation, monocytes from both dengue and OFIs patients had increased intracellular IL$1 \beta$ expression (Figure 2(b)), except in DSS patients which showed statistically significant decreased levels especially on Day +1 as compared with other groups $(P<0.05)$. For intracellular TNF- $\alpha$ expression on unstimulated monocytes, there was no statistical significant difference among the studied groups (Figure 2(c)). However, for LPS-stimulated monocytes, the intracellular TNF- $\alpha$ in DSS patients showed slightly decreased levels than other groups on Day 0 and Day +1 (Figure 2(d)).

3.5. Surface CD11b Expression on Peripheral Blood Monocytes. Surface CD11b fluorescence intensity on monocyte (CD14+) was determined by using flow cytometry and it was measured as an additional marker of monocyte activation. The levels of MFI of surface CD11b were not significantly different among the studied groups. DSS patients had the lowest level of MFI of surface CD11b especially on Day 0 and Day +1 (Figure 3 ). However, the MFI of surface CD11b in patients infected with dengue virus was significantly higher on Day -1 , Day 0 , and Day +1 than on the day of convalescence $(P<0.05)$.

3.6. Correlation Analysis. The negative correlations between IL-10 levels and unstimulated and LPS-stimulated intracellular IL- $1 \beta$ and MFI of CD11b expression were shown in Figure 4 with $r=-0.484(P=0.019) ; r=-0.604(P=0.002)$ and $r=-0.695(P=0.038)$ for IL-10 versus unstimulated 
TABLE 2: The distribution of studied samples followed by the day of illness related to fever.

\begin{tabular}{|c|c|c|c|c|c|c|c|}
\hline \multirow{2}{*}{ Diagnosis } & \multicolumn{6}{|c|}{ Day of illness related to fever } & \multirow{2}{*}{ Tota } \\
\hline & Day -2 & Day -1 & Day 0 & Day +1 & Day +2 & Conval & \\
\hline Dengue fever & 7 & 17 & 36 & 30 & 10 & 31 & 131 \\
\hline DHF grade I & 7 & 18 & 29 & 33 & 3 & 31 & 121 \\
\hline DHF grade II & 2 & 14 & 27 & 23 & 7 & 19 & 92 \\
\hline DSS & 2 & 6 & 9 & 11 & 9 & 11 & 48 \\
\hline OFIs & 3 & 6 & 8 & 6 & 4 & 7 & 34 \\
\hline Total & 21 & 61 & 109 & 103 & 33 & 99 & 426 \\
\hline
\end{tabular}

DHF: dengue hemorrhagic fever; DSS: dengue shock syndrome; OFIs: other febrile illnesses; Conval: convalescence.

TABLE 3: Mean of maximum, minimum, and percentage of increment of Hct in patients with DF, DHF grades I and II, DSS, and OFIs.

\begin{tabular}{|c|c|c|c|c|c|}
\hline & \multicolumn{5}{|c|}{ Type } \\
\hline & DF & DHF I & DHF II & DSS & OFIs \\
\hline Number of patients & 36 & 33 & 27 & 11 & 8 \\
\hline Maximum Hct (\%) & $39.5 \pm 4.0$ & $43.5 \pm 3.9$ & $44.7 \pm 4.3$ & $47.9 \pm 8.1$ & $35.6 \pm 6.1$ \\
\hline Minimum Hct (\%) & $34.6 \pm 3.8$ & $36.1 \pm 4.0$ & $35.7 \pm 4.7$ & $32.8 \pm 3.9$ & $31.0 \pm 5.9$ \\
\hline Mean increment of Hct (\%) & 14.4 & 21.1 & 26.0 & 37.7 & 12.8 \\
\hline
\end{tabular}

TABLE 4: Mean \pm SD of platelet counts in DF, DHF grades I and II, DSS, and OFIs patients, followed by the day of illness related to fever.

\begin{tabular}{|c|c|c|c|c|c|c|}
\hline \multicolumn{7}{|c|}{ Platelet count $\left(\times 10^{6} / \mathrm{L}\right)$} \\
\hline Type & Day -2 & Day -1 & Day 0 & Day 1 & Day 2 & Conval $^{*}$ \\
\hline $\begin{array}{l}\mathrm{DF} \\
(n)\end{array}$ & $\begin{array}{c}115 \pm 33 \\
(7)\end{array}$ & $\begin{array}{c}112 \pm 41^{* *} \\
(17)\end{array}$ & $\begin{array}{c}85 \pm 34^{* *} \\
(36)\end{array}$ & $\begin{array}{c}86 \pm 31^{* *} \\
(30)\end{array}$ & $\begin{array}{c}129 \pm 47^{9} \\
(10)\end{array}$ & $\begin{array}{c}360 \pm 131 \\
(31)\end{array}$ \\
\hline $\begin{array}{l}\text { DHF I } \\
(n)\end{array}$ & $\begin{array}{c}77 \pm 29 \\
(7)\end{array}$ & $\begin{array}{c}64 \pm 32 \\
(18)\end{array}$ & $\begin{array}{c}61 \pm 26 \\
(29)\end{array}$ & $\begin{array}{c}56 \pm 25 \\
(33)\end{array}$ & $\begin{array}{c}59 \pm 44 \\
(3)\end{array}$ & $\begin{array}{c}376 \pm 147 \\
(31)\end{array}$ \\
\hline $\begin{array}{l}\text { DHF II } \\
(n)\end{array}$ & $\begin{array}{c}65 \pm 37 \\
(2)\end{array}$ & $\begin{array}{c}66 \pm 30 \\
(14)\end{array}$ & $\begin{array}{c}52 \pm 26 \\
(27)\end{array}$ & $\begin{array}{c}57 \pm 34 \\
(23)\end{array}$ & $\begin{array}{c}72 \pm 53 \\
(7)\end{array}$ & $\begin{array}{c}319 \pm 99 \\
(19)\end{array}$ \\
\hline $\begin{array}{l}\text { DSS } \\
(n)\end{array}$ & $\begin{array}{c}80 \pm 49 \\
(2)\end{array}$ & $\begin{array}{c}63 \pm 46 \\
(6)\end{array}$ & $\begin{array}{c}40 \pm 20^{¥} \\
\text { (9) }\end{array}$ & $\begin{array}{c}61 \pm 44 \\
(11)\end{array}$ & $\begin{array}{c}51 \pm 40 \\
\quad(9)\end{array}$ & $\begin{array}{c}385 \pm 77 \\
(11)\end{array}$ \\
\hline $\begin{array}{l}\text { OFIs } \\
(n)\end{array}$ & $\begin{array}{c}110 \pm 41 \\
(3)\end{array}$ & $\begin{array}{c}128 \pm 15 \\
(6)\end{array}$ & $\begin{array}{c}147 \pm 69^{\ddagger} \\
(8)\end{array}$ & $\begin{array}{c}126 \pm 51 \\
(6)\end{array}$ & $\begin{array}{c}124 \pm 29 \\
(4)\end{array}$ & $\begin{array}{c}310 \pm 66 \\
(7)\end{array}$ \\
\hline
\end{tabular}

Conval $^{*}=$ Convalescence.

DF versus DHF/DSS: ${ }^{* *} P<0.05$; DSS versus DF, DHF I, and OFIs: ${ }^{\ddagger} P<0.05$.

OFIs versus DHF/DSS: ${ }^{\ddagger} P<0.05$; DF versus DHF/DSS: ${ }^{9} P<0.05$.

TABLE 5: Mean \pm SD of the level of interleukin-10 (IL-10) in patients with DF, DHF grades I and II, DSS, and OFIs patients, followed by the day of illness related to fever.

\begin{tabular}{|c|c|c|c|c|c|c|}
\hline \multicolumn{7}{|c|}{ IL-10 (pg/mL) } \\
\hline Type & Day -2 & Day -1 & Day 0 & Day +1 & Day +2 & Conval $^{*}$ \\
\hline $\begin{array}{l}\text { DF } \\
(n)\end{array}$ & $\begin{array}{c}44.0 \pm 28.8 \\
(7)\end{array}$ & $\begin{array}{c}41.1 \pm 22.9^{* *} \\
(17)\end{array}$ & $\begin{array}{c}56.7 \pm 37.5 \\
(36)\end{array}$ & $\begin{array}{c}29.0 \pm 14.3 \\
(30)\end{array}$ & $\begin{array}{l}14.4 \pm 10.1 \\
\quad(10)\end{array}$ & $\begin{array}{c}1.2 \pm 0.7 \\
(31)\end{array}$ \\
\hline $\begin{array}{l}\text { DHF I } \\
(n)\end{array}$ & $\begin{array}{c}19.4 \pm 11.6 \\
(7)\end{array}$ & $\begin{array}{c}93.4 \pm 41.8 \\
(18)\end{array}$ & $\begin{array}{l}55.3 \pm 32.8 \\
(29)\end{array}$ & $\begin{array}{l}19.7 \pm 11.5 \\
(33)\end{array}$ & $\begin{array}{c}8.5 \pm 6.3 \\
(3)\end{array}$ & $\begin{array}{l}1.2 \pm 1.0 \\
(31)\end{array}$ \\
\hline $\begin{array}{l}\text { DHF II } \\
(n)\end{array}$ & $\begin{array}{c}52.3 \pm 34.9 \\
(2)\end{array}$ & $\begin{array}{c}125.6 \pm 60.1 \\
(14)\end{array}$ & $\begin{array}{l}57.8 \pm 34.3 \\
(27)\end{array}$ & $\begin{array}{l}25.3 \pm 14.4 \\
(23)\end{array}$ & $\begin{array}{c}10.2 \pm 7.4 \\
(7)\end{array}$ & $\begin{array}{c}1.1 \pm 0.6 \\
(19)\end{array}$ \\
\hline $\begin{array}{l}\text { DSS } \\
(n)\end{array}$ & $\begin{array}{c}29.1 \pm 11.2 \\
(2)\end{array}$ & $\begin{array}{c}153.6 \pm 65.0 \\
(6)\end{array}$ & $\begin{array}{c}41.6 \pm 25.4 \\
(9)\end{array}$ & $\begin{array}{c}68.5 \pm 40.7^{9} \\
(11)\end{array}$ & $\begin{array}{c}16.5 \pm 10.7 \\
(9)\end{array}$ & $\begin{array}{c}1.0 \pm 0.4 \\
\quad(13)\end{array}$ \\
\hline $\begin{array}{l}\text { OFIs } \\
(n)\end{array}$ & $\begin{array}{c}2.9 \pm 2.0 \\
(3)\end{array}$ & $\begin{array}{c}28.5 \pm 15.9^{¥} \\
(6)\end{array}$ & $\begin{array}{c}17.9 \pm 10.1^{\ddagger} \\
(8)\end{array}$ & $\begin{array}{c}8.8 \pm 6.6 \\
(6)\end{array}$ & $\begin{array}{c}7.8 \pm 3.6 \\
(4)\end{array}$ & $\begin{array}{c}0.8 \pm 0.2 \\
(7)\end{array}$ \\
\hline
\end{tabular}

Conval $^{*}=$ Convalescence.

DF versus DHF/DSS: ${ }^{* *} P<0.01$; OFIs versus DHF/DSS: ${ }^{\sharp} P<0.05$.

OFIs versus dengue (DF + DHF): ${ }^{\ddagger} P<0.05$; DSS versus DF and OFIs: ${ }^{9} P<0.05$. 


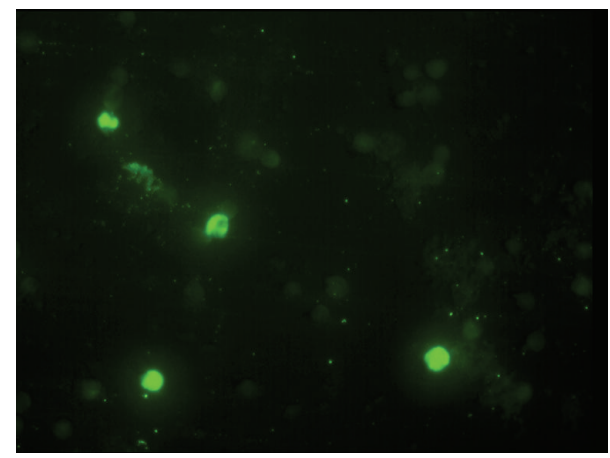

(a)

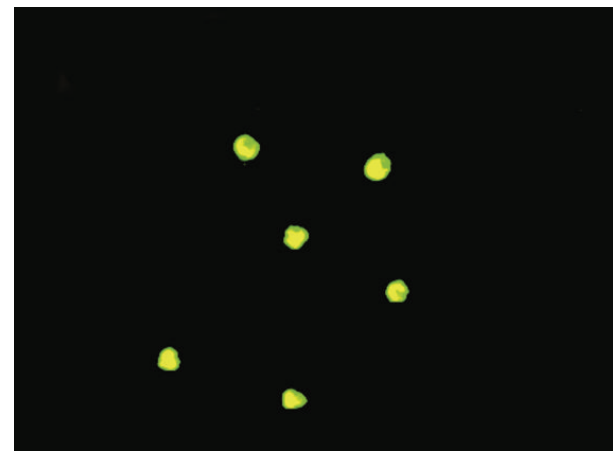

(b)

FIGURE 1: Demonstration of dengue viral antigen in monocytes of patients infected with dengue virus as dengue viral antigen positive-stained cells in panel (a) and double-stained for dengue viral antigen and CD14 positive cells in panel (b).

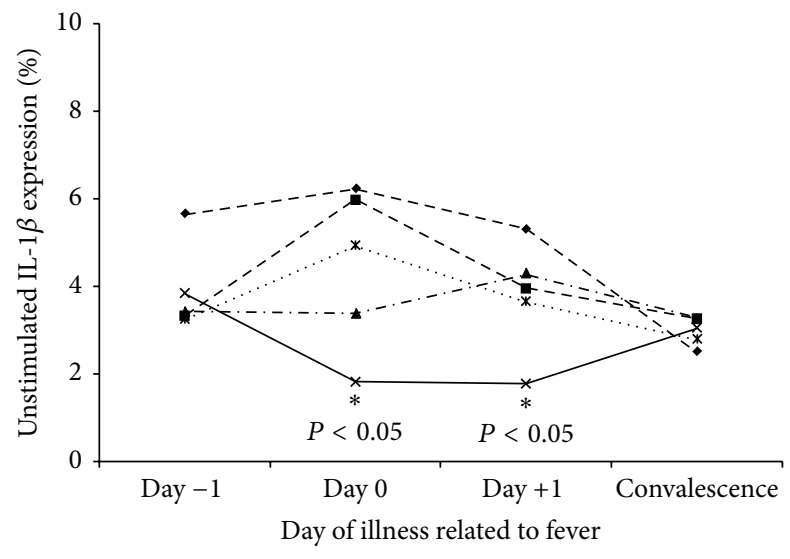

(a)

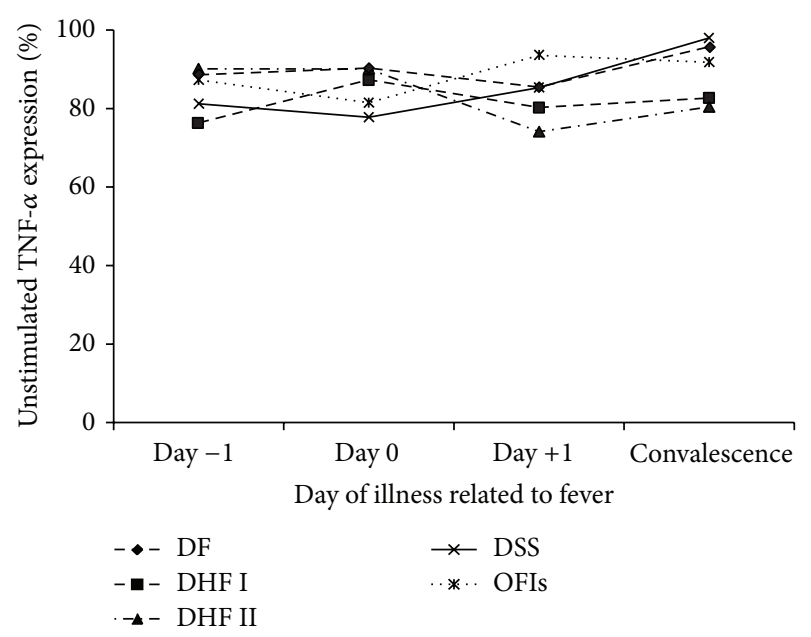

(c)

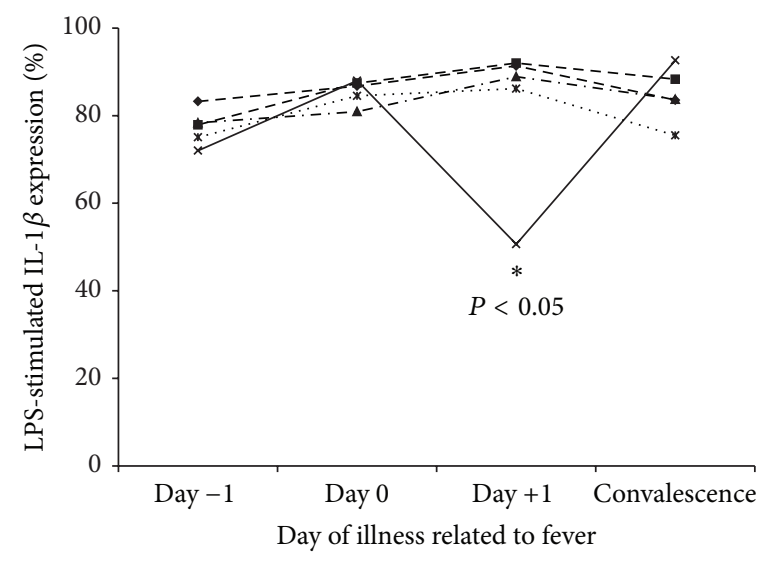

(b)

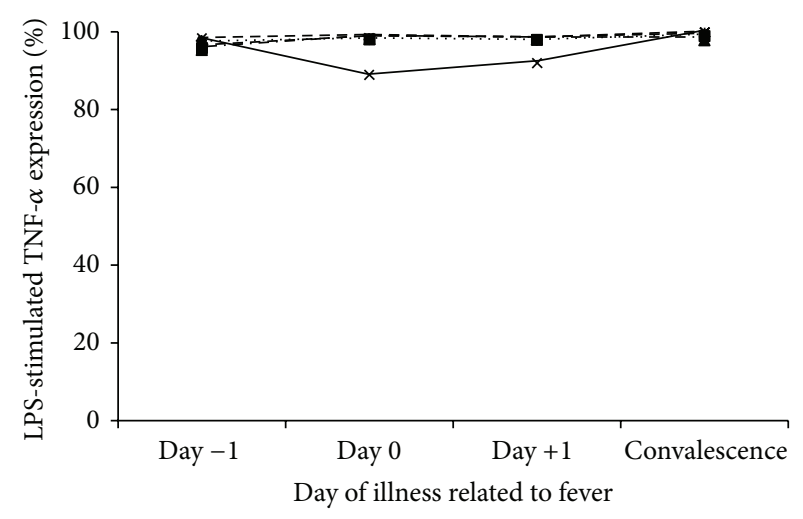

(d)

FIGURE 2: Mean levels of \% expression of unstimulated and LPS-stimulated intracellular IL-1 $\beta$ ((a) and (b)) and mean levels of \% expression of unstimulated and LPS-stimulated intracellular TNF- $\alpha$ ((c) and (d)) in monocytes of DF, DHF grades I and II, DSS, and OFIs patients, followed by the day of illness related to fever. 
TABLE 6: Mean \pm SD of the level of tumor necrosis factor-alpha (TNF- $\alpha$ ) in patients with DF, DHF grades I and II, DSS, and OFIs patients, followed by the day of illness related to fever.

\begin{tabular}{|c|c|c|c|c|c|c|}
\hline \multicolumn{7}{|c|}{ TNF- $\alpha(\mathrm{pg} / \mathrm{mL})$} \\
\hline Type & Day -2 & Day -1 & Day 0 & Day +1 & Day +2 & Conval $^{*}$ \\
\hline $\begin{array}{l}\mathrm{DF} \\
(n)\end{array}$ & $\begin{array}{c}4.0 \pm 2.0 \\
(7)\end{array}$ & $\begin{array}{c}4.1 \pm 2.0 \\
(17)\end{array}$ & $\begin{array}{c}4.3 \pm 1.9^{\ddagger} \\
(36)\end{array}$ & $\begin{array}{c}3.8 \pm 1.5 \\
(30)\end{array}$ & $\begin{array}{c}3.5 \pm 1.2 \\
(10)\end{array}$ & $\begin{array}{c}2.3 \pm 0.9 \\
(31)\end{array}$ \\
\hline $\begin{array}{l}\text { DHF I } \\
(n)\end{array}$ & $\begin{array}{c}4.2 \pm 1.3 \\
(7)\end{array}$ & $\begin{array}{c}4.4 \pm 1.6 \\
(18)\end{array}$ & $\begin{array}{c}3.3 \pm 1.5 \\
(29)\end{array}$ & $\begin{array}{c}3.1 \pm 1.0 \\
(33)\end{array}$ & $\begin{array}{c}2.2 \pm 0.1 \\
\text { (3) }\end{array}$ & $\begin{array}{c}2.3 \pm 1.2 \\
(31)\end{array}$ \\
\hline $\begin{array}{l}\text { DHF II } \\
(n)\end{array}$ & $\begin{array}{c}5.7 \pm 2.4 \\
(2)\end{array}$ & $\begin{array}{c}5.1 \pm 1.5 \\
\quad(14)\end{array}$ & $\begin{array}{c}3.8 \pm 1.4 \\
\quad(27)\end{array}$ & $\begin{array}{c}3.5 \pm 1.6 \\
(23)\end{array}$ & $\begin{array}{c}3.0 \pm 1.1 \\
(7)\end{array}$ & $\begin{array}{c}2.1 \pm 0.7 \\
(19)\end{array}$ \\
\hline $\begin{array}{l}\text { DSS } \\
(n)\end{array}$ & $\begin{array}{c}4.1 \pm 1.7 \\
(2)\end{array}$ & $\begin{array}{c}4.1 \pm 2.5 \\
(6)\end{array}$ & $\begin{array}{c}2.8 \pm 1.8^{\ddagger} \\
(9)\end{array}$ & $\begin{array}{c}4.8 \pm 2.6^{9} \\
(11)\end{array}$ & $\begin{array}{c}3.4 \pm 1.3 \\
(9)\end{array}$ & $\begin{array}{c}2.4 \pm 0.8 \\
(13)\end{array}$ \\
\hline $\begin{array}{l}\text { OFIs } \\
(n)\end{array}$ & $\begin{array}{c}2.7 \pm 2.0 \\
(3)\end{array}$ & $\begin{array}{c}3.7 \pm 1.1^{* *} \\
(6)\end{array}$ & $\begin{array}{c}3.2 \pm 1.6 \\
(8)\end{array}$ & $\begin{array}{c}4.2 \pm 3.1 \\
(6)\end{array}$ & $\begin{array}{c}4.7 \pm 2.7^{\ddagger \ddagger} \\
(4)\end{array}$ & $\begin{array}{c}2.3 \pm 0.4 \\
(7)\end{array}$ \\
\hline
\end{tabular}

Conval $^{*}=$ convalescence.

DHF II versus OFIs: ${ }^{* *} P<0.05$; DF versus DHF I and DSS: ${ }^{¥} P<0.05$.

DSS versus DF and DHF II: ${ }^{\ddagger} P<0.05$; DSS versus DHF I: ${ }^{9} P<0.05$.

DHF I versus OFIs: ${ }^{\ddagger \ddagger} P<0.05$.

TABLE 7: Mean \pm SD of the level of interleukin-1 beta (IL-1 $\beta$ ) in patients with DF, DHF grades I and II, DSS, and OFIs patients, followed by the day of illness related to fever.

\begin{tabular}{|c|c|c|c|c|c|c|}
\hline \multicolumn{7}{|c|}{$\mathrm{IL}-1 \beta(\mathrm{pg} / \mathrm{mL})$} \\
\hline Type & Day -2 & Day -1 & Day 0 & Day +1 & Day +2 & Conval $^{*}$ \\
\hline $\begin{array}{l}\text { DF } \\
(n)\end{array}$ & $\begin{array}{c}0.5 \pm 0.2 \\
(7)\end{array}$ & $\begin{array}{c}2.7 \pm 2.7 \\
(17)\end{array}$ & $\begin{array}{c}2.1 \pm 1.7 \\
(36)\end{array}$ & $\begin{array}{c}2.4 \pm 1.2 \\
\quad(30)\end{array}$ & $\begin{array}{c}2.1 \pm 1.5 \\
(10)\end{array}$ & $\begin{array}{c}1.2 \pm 1.3 \\
(31)\end{array}$ \\
\hline $\begin{array}{l}\text { DHF I } \\
(n)\end{array}$ & $\begin{array}{c}1.0 \pm 0.7 \\
(7)\end{array}$ & $\begin{array}{c}1.0 \pm 0.9 \\
(18)\end{array}$ & $\begin{array}{c}1.1 \pm 1.1 \\
(29)\end{array}$ & $\begin{array}{c}1.3 \pm 1.4 \\
(33)\end{array}$ & $\begin{array}{c}0.4 \pm 0.2 \\
\text { (3) }\end{array}$ & $\begin{array}{c}1.0 \pm 1.2 \\
(31)\end{array}$ \\
\hline $\begin{array}{l}\text { DHF II } \\
(n)\end{array}$ & $\begin{array}{c}0.5 \pm 0.1 \\
(2)\end{array}$ & $\begin{array}{c}0.8 \pm 1.1 \\
\quad(14)\end{array}$ & $\begin{array}{c}1.0 \pm 1.1 \\
(27)\end{array}$ & $\begin{array}{c}0.9 \pm 1.1 \\
(23)\end{array}$ & $\begin{array}{c}0.8 \pm 0.7 \\
(7)\end{array}$ & $\begin{array}{c}1.0 \pm 1.1 \\
(19)\end{array}$ \\
\hline $\begin{array}{l}\text { DSS } \\
(n)\end{array}$ & $\begin{array}{c}0.6 \pm 0.01 \\
\text { (2) }\end{array}$ & $\begin{array}{c}1.4 \pm 0.7 \\
(6)\end{array}$ & $\begin{array}{c}1.0 \pm 0.9 \\
(9)\end{array}$ & $\begin{array}{c}0.9 \pm 0.7 \\
\quad(11)\end{array}$ & $\begin{array}{c}0.8 \pm 0.4 \\
(9)\end{array}$ & $\begin{array}{c}1.2 \pm 0.7 \\
(13)\end{array}$ \\
\hline $\begin{array}{l}\text { OFIs } \\
(n)\end{array}$ & $\begin{array}{c}0.8 \pm 0.2 \\
\text { (3) }\end{array}$ & $\begin{array}{c}1.9 \pm 3.0 \\
(6)\end{array}$ & $\begin{array}{c}1.9 \pm 1.9 \\
(8)\end{array}$ & $\begin{array}{c}2.2 \pm 2.4 \\
(6)\end{array}$ & $\begin{array}{c}1.4 \pm 1.1 \\
(4)\end{array}$ & $\begin{array}{c}0.9 \pm 0.4 \\
(7)\end{array}$ \\
\hline
\end{tabular}

Conval $^{*}=$ Convalescence.

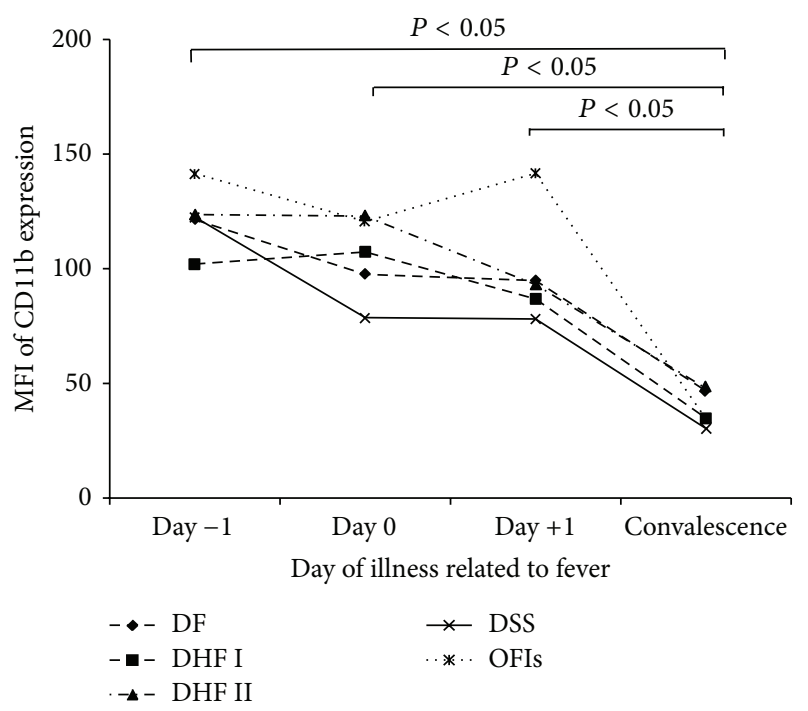

FIGURE 3: The mean fluorescence intensity (MFI) of surface CD11b expression on the surface of monocytes in DF, DHF grades I and II, DSS, and OFIs patients, followed by the day of illness related to fever (unit as a.u. or arbitrary units of fluorescence).
IL-1 $\beta$, versus LPS-stimulated IL- $1 \beta$, and versus MFI of CD11b expression, respectively.

\section{Discussion}

Pathogenesis of DHF has not been completely understood. There are many hypotheses that have been studied to explain the vascular leakage phenomenon in DHF especially in DSS. Vascular leakage occurs when endothelial cells are activated or damaged and are followed by the loss of their barrier function. There are many causes of endothelial cells activation that have been investigated in dengue virus infection such as dengue virus itself, secretion from monocyte/macrophage, complement activation, and cytokine production $[9,31-$ 33]. In this study, monocyte status and various kinds of mediators related to monocytes were investigated in order to understand the mechanism related to vascular leakage and immune responses in patients infected with dengue virus.

Several studies reported that monocytes are proposed to be the primary target cells of dengue virus infection in human $[6,7]$. Dengue virus infected cultured human monocytes can increase TNF- $\alpha$ expression and apoptosis [34]. This study 


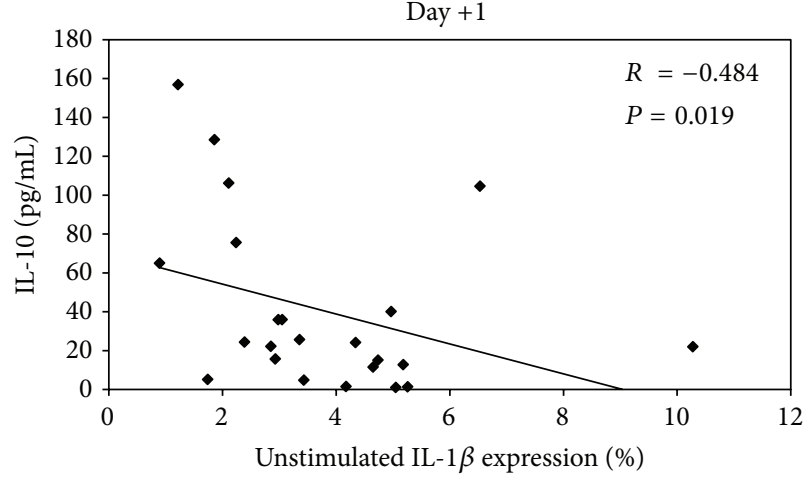

(a)

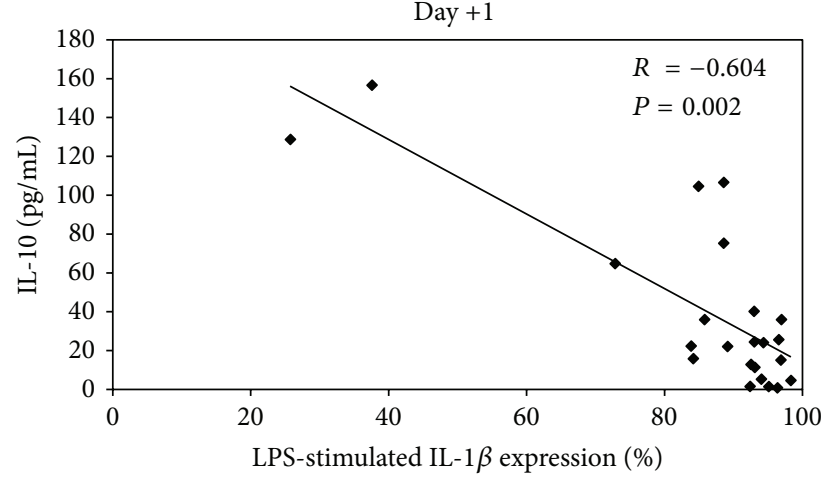

(b)

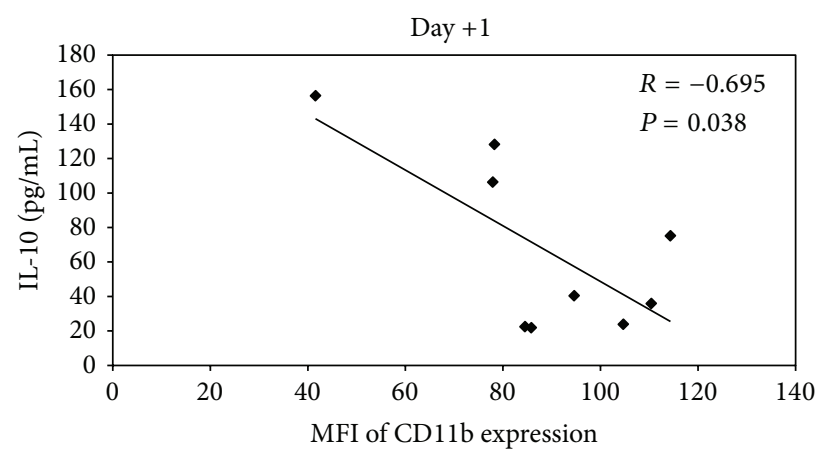

(c)

FIGURE 4: Correlation between IL-10 levels versus unstimulated and LPS-stimulated intracellular IL-1 $\beta$ expression ((a) and (b)) and versus MFI of CD11b expression (c) in DHF patients.

demonstrated the presentation of dengue viral antigen in monocytes among PBMCs of patients infected with dengue virus. Recently, Durbin et al. [4] characterized the phenotype of PBMCs from patients infected with dengue virus and found that the cells containing dengue antigen expressed the phenotype typical of activated peripheral blood monocytes. The findings in this study confirm the evidence that monocytes are the target cells of dengue viral infection in human peripheral blood. CD11b expression is used to be a marker of monocyte activation in vivo and plays an important role in the recruitment of PMNs and monocytes to the sites of infection [34]. Previous studies have shown a higher level of CD11b expression on monocytes in many diseases [35, 36]. Activated monocyte was also found to play a potential role in the activation of vascular endothelium, as well as monocyte adherence which is related to IL-10 secretion [37, 38]. In this study, the monocytes activation was detected as demonstrated by the increased CD11b expression in all types of studied groups as compared to the day of convalescences. Astonishingly, the lowest expression of CD11b on monocytes was detected in DSS patients especially in febrile and toxic stages as previously reported that the IL-10 could suppress CD11b expression $[38,39]$.

Dengue-infected monocytes could stimulate cytokines/ chemokines production (e.g., TNF- $\alpha$ and IL-1 $\beta$ ) which are known to activate endothelial cell. TNF- $\alpha$ and IL- $1 \beta$ act locally on endothelial cells to increase vascular permeability and adhesion molecules expression, facilitating blood leukocyte adherence and diapedesis [8, 31, 40]. Accordingly, the determination for the expression of intracellular cytokines in dengue-infected monocytes, that is, TNF- $\alpha$ and IL-1 $\beta$, as unstimulated and LPS-stimulated conditions in the presence of BFA, which prevented the secretion of any intracellular cytokine that had accumulated in the cytoplasm [41], showed that both circulating unstimulated and LPSstimulated monocytes from DSS patients reduced the IL-1 $\beta$ and TNF- $\alpha$ production less than the other groups. These findings are similar to the report of Suharti et al. which has studied patients with DSS and found that the ex vivo LPSstimulated production of the proinflammatory cytokines TNF- $\alpha$ and IL-1 $\beta$ were considerably depressed but returned to normal on recovery [42]. One possible reason is that the continuous activation of monocytes might reduce the capacity of the cells to produce cytokines in response to physiological agonists then leading to monocyte exhaustion. Another reason of downregulation of intracellular cytokines may result from the action of the anti-inflammatory cytokine IL-10 which may reflect a physiologic counter response to the proinflammatory cytokine production by various mechanisms [43-45]. However, IL-10 has been shown to be increased in DHF patients associated with the degree of plasma leakage quantified by the size of the pleural effusion $[18,19]$. Also, IL-10 was found to be associated with reduction of $\mathrm{T}$ cells and $\mathrm{T}$ cell apoptosis [46]. In addition, this study found the highest level of IL-10 in DSS patients which has negative correlation with the percentages of intracellular 
IL-1 $\beta$ expression in both unstimulated and LPS-stimulated monocytes especially in DHF patients. Furthermore, the negative correlation between IL-10 and MFI of CD11b expression in DHF patients which indicated the monocytes exhaustion was also demonstrated.

In summary, these results render support of enhanced both proinflammatory cytokine TNF- $\alpha$ and anti-inflammatory cytokine IL-10 production in accordance with the clinical grading of dengue viral infection. The cause and effect relationship of these cytokines as well as hematological changes and monocyte status regarding the clinical severity may explain the mechanism leading to vascular leakage in severe dengue-infected patients.

\section{Conflict of Interests}

The authors have no conflict of interests.

\section{Acknowledgments}

The authors would like to thank staff of Pediatric Ward, Faculty of Medicine Ramathibodi Hospital, Mahidol University, for their assistance in sample collection and members of Blood Diseases Diagnostic Center, Division of Hematology, Department of Pathology, Faculty of Medicine Ramathibodi Hospital, for technical services. The study was supported by TRF-Royal Golden Jubilee Ph.D. Program (Grant no. PHD/0003/2549) to Sirichan Chunhakan and Associate Professor Dr. Punnee Butthep and The Thailand Research Fund (TRF) Senior Research Scholar Award to Professor Ampaiwan Chuansumrit.

\section{References}

[1] B. E. E. Martina, P. Koraka, and A. D. M. E. Osterhaus, "Dengue virus pathogenesis: an integrated view," Clinical Microbiology Reviews, vol. 22, no. 4, pp. 564-581, 2009.

[2] A. B. Pérez, B. Sierra, G. Garcia et al., "Tumor necrosis factoralpha, transforming growth factor- $\beta 1$, and interleukin-10 gene polymorphisms: implication in protection or susceptibility to dengue hemorrhagic fever," Human Immunology, vol. 71, no. 11, pp. 1135-1140, 2010.

[3] K. Jessie, M. Y. Fong, S. Devi, S. K. Lam, and K. T. Wong, "Localization of dengue virus in naturally infected human tissues, by immunohistochemistry and in situ hybridization," Journal of Infectious Diseases, vol. 189, no. 8, pp. 1411-1418, 2004.

[4] A. P. Durbin, M. J. Vargas, K. Wanionek et al., "Phenotyping of peripheral blood mononuclear cells during acute dengue illness demonstrates infection and increased activation of monocytes in severe cases compared to classic dengue fever," Virology, vol. 376, no. 2, pp. 429-435, 2008.

[5] I. Kurane and F. A. Ennis, "Production of interferon alpha by dengue virus-infected human monocytes," Journal of General Virology, vol. 69, no. 2, pp. 445-449, 1988.

[6] Z. Kou, M. Quinn, H. Chen et al., "Monocytes, but not T or $\mathrm{B}$ cells, are the principal target cells for dengue virus (DV) infection among human peripheral blood mononuclear cells," Journal of Medical Virology, vol. 80, no. 1, pp. 134-146, 2008.

[7] I. Bosch, K. Xhaja, L. Estevez et al., "Increased production of interleukin-8 in primary human monocytes and in human epithelial and endothelial cell lines after dengue virus challenge," Journal of Virology, vol. 76, no. 11, pp. 5588-5597, 2002.

[8] Y.-C. Chen and S.-Y. Wang, "Activation of terminally differentiated human monocytes/macrophages by dengue virus: productive infection, hierarchical production of innate cytokines and chemokines, and the synergistic effect of lipopolysaccharide," Journal of Virology, vol. 76, no. 19, pp. 9877-9887, 2002.

[9] J. M. Carr, H. Hocking, K. Bunting et al., "Supernatants from dengue virus type- 2 infected macrophages induce permeability changes in endothelial cell monolayers," Journal of Medical Virology, vol. 69, no. 4, pp. 521-528, 2003.

[10] S. B. Halstead, "Pathogenisis of dengue: challenges to molecular biology," Science, vol. 239, no. 4839, pp. 476-481, 1988.

[11] S. B. Halstead, "Dengue," The Lancet, vol. 370, no. 9599, pp. 1644-1652, 2007.

[12] D. F. Mangan and S. M. Wahl, "Differential regulation of human monocyte programmed cell death (apoptosis) by chemotactic factors and pro-inflammatory cytokines," Journal of Immunology, vol. 147, no. 10, pp. 3408-3412, 1991.

[13] D. F. Mngan, G. R. Welch, and S. M. Wahl, "Lipopolysaccharide, tumor necrosis factor- $\alpha$, and IL- $1 \beta$ prevent programmed cell death (apoptosis) in human peripheral blood monocytes," The Journal of Immunology, vol. 146, no. 5, pp. 1541-1546, 1991.

[14] D. M. Mosser and X. Zhang, "Interleukin-10: new perspectives on an old cytokine," Immunological Reviews, vol. 226, no. 1, pp. 205-218, 2008.

[15] G. N. Malavige, L. Gomes, L. Alles et al., "Serum IL-10 as a marker of severe dengue infection," BMC Infectious Diseases, vol. 13, no. 1, article 341, 2013.

[16] T.-T. Tsai, Y.-J. Chuang, Y.-S. Lin, S.-W. Wan, C.-L. Chen, and C.-F. Lin, "An emerging role for the anti-inflammatory cytokine interleukin-10 in dengue virus infection," Journal of Biomedical Science, vol. 20, article 40, 2013.

[17] K. I. Schexneider and E. A. Reedy, "Thrombocytopenia in dengue fever," Current Hematology Reports, vol. 4, no. 2, pp. 145148, 2005.

[18] S. Green, D. W. Vaughn, S. Kalayanarooj et al., "Elevated plasma interleukin-10 levels in acute dengue correlate with disease severity," Journal of Medical Virology, vol. 59, no. 3, pp. 329-334, 1999.

[19] E. L. Azeredo, S. M. O. Zagne, M. A. Santiago et al., "Characterisation of lymphocyte response and cytokine patterns with dengue fever," Immunobiology, vol. 204, no. 4, pp. 494-507, 2001.

[20] D. H. Libraty, T. P. Endy, H.-S. H. Houng et al., "Differing influences of virus burden and immune activation on disease severity in secondary dengue-3 virus infections," Journal of Infectious Diseases, vol. 185, no. 9, pp. 1213-1221, 2002.

[21] J. Mongkolsapaya, W. Dejnirattisai, X.-N. Xu et al., "Original antigenic sin and apoptosis in the pathogenesis of dengue hemorrhagic fever," Nature Medicine, vol. 9, no. 7, pp. 921-927, 2003.

[22] A. B. Pérez, G. García, B. Sierra et al., "IL-10 levels in dengue patients: some findings from the exceptional epidemiological conditions in Cuba," Journal of Medical Virology, vol. 73, no. 2, pp. 230-234, 2004.

[23] S. Chunhakan, P. Butthep, S. Yoksan, K. Tangnararatchakit, and A. Chuansumrit, "Early diagnosis of dengue virus infection by detection of dengue viral antigen in peripheral blood mononuclear cell," Pediatric Infectious Disease Journal, vol. 28, no. 12, pp. 1085-1088, 2009. 
[24] P. Butthep, S. Chunhakan, S. Yoksan, K. Tangnararatchakit, and A. Chuansumrit, "Alteration of cytokines and chemokines during febrile episodes associated with endothelial cell damage and plasma leakage in dengue hemorrhagic fever," Pediatric Infectious Disease Journal, vol. 31, no. 12, pp. e232-e238, 2012.

[25] World Health Organization, Dengue Hemorrhagic Fever: Diagnosis, Treatment, Prevention and Control, World Health Organization, Geneva, Switzerland, 2nd edition, 1997.

[26] L. Rosen and D. Gubler, "The use of mosquitos to detect and propagate dengue viruses," The American Journal of Tropical Medicine and Hygiene, vol. 23, no. 6, pp. 1153-1160, 1974.

[27] B. L. Innis, A. Nisalak, S. Nimmannitya et al., "An enzymelinked immunosorbent assay to characterize dengue infections where dengue and Japanese encephalitis co-circulate," American Journal of Tropical Medicine and Hygiene, vol. 40, no. 4, pp. 418427, 1989.

[28] A. J. Johnson, D. A. Martin, N. Karabatsos, and J. T. Roehrig, "Detection of anti-arboviral immunoglobulin $\mathrm{G}$ by using a monoclonal antibody-based capture enzyme-linked immunosorbent assay," Journal of Clinical Microbiology, vol. 38, no. 5, pp. 1827-1831, 2000.

[29] P. Butthep, S. Rummavas, R. Wisedpanichkij, S. Jindadamrongwech, S. Fucharoen, and A. Bunyaratvej, "Increased circulating activated endothelial cells, vascular endothelial growth factor, and tumor necrosis factor in thalassemia," American Journal of Hematology, vol. 70, no. 2, pp. 100-106, 2002.

[30] M. M. Khin, N. Bhamarapravati, S. Yoksan, J. Rabablert, and P. Cipkokwai, "Study of infection and biological attributes of the dengue 1 viruses recovered from human volunteers immunized with dengue 1 candidate vaccine after oral infection of Aedes aegypti," The Southeast Asian Journal of Tropical Medicine and Public Health, vol. 21, no. 4, p. 709, 1990.

[31] R. Anderson, S. Wang, C. Osiowy, and A. C. Issekutz, "Activation of endothelial cells via antibody-enhanced dengue virus infection of peripheral blood monocytes," Journal of Virology, vol. 71, no. 6, pp. 4226-4232, 1997.

[32] P. Avirutnan, P. Malasit, B. Seliger, S. Bhakdi, and M. Husmann, "Dengue virus infection of human endothelial cells leads to chemokine production, complement activation, and apoptosis," Journal of Immunology, vol. 161, no. 11, pp. 6338-6346, 1998.

[33] C.-F. Lin, S.-C. Chiu, Y.-L. Hsiao et al., "Expression of cytokine, chemokine, and adhesion molecules during endothelial cell activation induced by antibodies against dengue virus nonstructural protein 1," The Journal of Immunology, vol. 174, no. 1, pp. 395-403, 2005.

[34] L. M. Espina, N. J. Valero, J. M. Hernández, and J. A. Mosquera, "Increased apoptosis and expression of tumor necrosis factor- $\alpha$ caused by infection of cultured human monocytes with dengue virus," The American Journal of Tropical Medicine and Hygiene, vol. 68, no. 1, pp. 48-53, 2003.

[35] J. P. Buyon, N. Shadick, R. Berkman et al., "Surface expression of gp165/95, the complement receptor CR3, as a marker of disease activity in systemic lupus erythematosus," Clinical Immunology and Immunopathology, vol. 46, no. 1, pp. 141-149, 1988.

[36] D. S. Kyriakou, M. G. Alexandrakis, E. S. Kyriakou et al., "Activated peripheral blood and endothelial cells in thalassemia patients," Annals of Hematology, vol. 80, no. 10, pp. 577-583, 2001.

[37] J. D. Belcher, P. H. Marker, J. P. Weber, R. P. Hebbel, and G. M. Vercellotti, "Activated monocytes in sickle cell disease: Potential role in the activation of vascular endothelium and vaso-occlusion," Blood, vol. 96, no. 7, pp. 2451-2459, 2000.
[38] A.-F. Petit-Bertron, C. Fitting, J.-M. Cavaillon, and M. AdibConquy, "Adherence influences monocyte responsiveness to interleukin-10," Journal of Leukocyte Biology, vol. 73, no. 1, pp. 145-154, 2003.

[39] J. Paysant, M. Vasse, J. Soria et al., "Regulation of the uPAR/uPA system expressed on monocytes by the deactivating cytokines, IL-4, IL-10 and IL-13: consequences on cell adhesion to vitronectin and fibrinogen," British Journal of Haematology, vol. 100, no. 1, pp. 45-51, 1998.

[40] T. M. Carlos and J. M. Harlan, "Leukocyte-endothelial adhesion molecules," Blood, vol. 84, no. 7, pp. 2068-2101, 1994.

[41] T. Jung, U. Schauer, C. Heusser, C. Neumann, and C. Rieger, "Detection of intracellular cytokines by flow cytometry," Journal of Immunological Methods, vol. 159, no. 1-2, pp. 197-207, 1993.

[42] C. Suharti, E. C. M. van Gorp, W. M. V. Dolmans et al., "Cytokine patterns during dengue shock syndrome," European Cytokine Network, vol. 14, no. 3, pp. 172-177, 2003.

[43] R. de Waal Malefyt, J. Haanen, H. Spits et al., "Interleukin 10 (IL10) and viral IL-10 strongly reduce antigen-specific human T cell proliferation by diminishing the antigen-presenting capacity of monocytes via downregulation of class II major histocompatibility complex expression," Journal of Experimental Medicine, vol. 174, no. 4, pp. 915-924, 1991.

[44] M. A. Cassatella, L. Meda, S. Bonora, M. Ceska, and G. Constantin, "Interleukin 10 (IL-10) inhibits the release of proinflammatory cytokines from human polymorphonuclear leukocytes. Evidence for an autocrine role of tumor necrosis factor and IL- $1 \beta$ in mediating the production of IL- 8 triggered by lipopolysaccharide," Journal of Experimental Medicine, vol. 178, no. 6, pp. 2207-2211, 1993.

[45] K. W. Moore, A. O’Garra, R. de Waal Malefyt, P. Vieira, and T. R. Mosmann, "Interleukin-10," Annual Review of Immunology, vol. 11, pp. 165-190, 1993.

[46] G. N. Malavige, L.-C. Huang, M. Salimi, L. Gomes, S. D. Jayaratne, and G. S. Ogg, "Cellular and cytokine correlates of severe dengue infection," PLoS ONE, vol. 7, no. 11, Article ID e50387, 2012. 


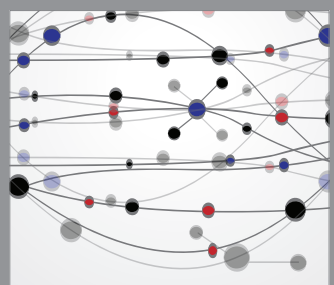

The Scientific World Journal
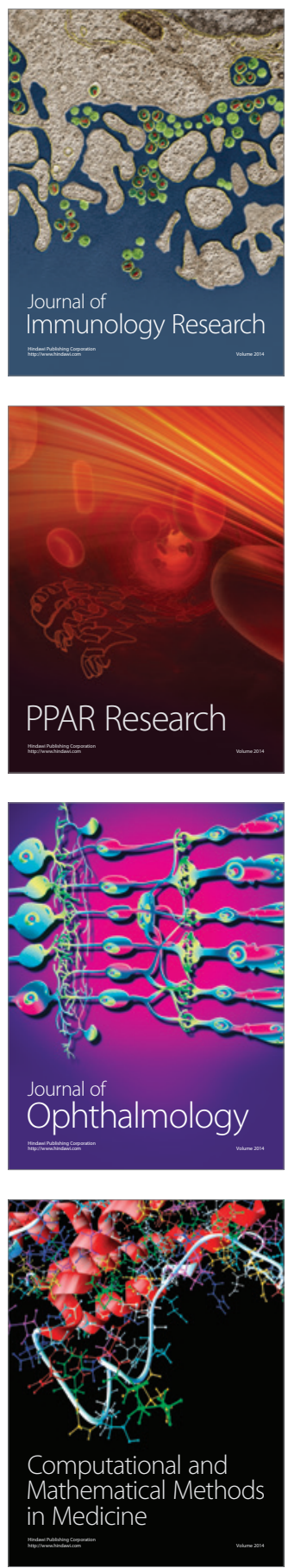

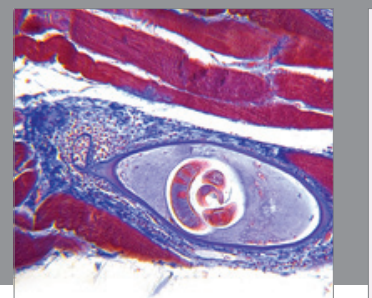

Gastroenterology

Research and Practice
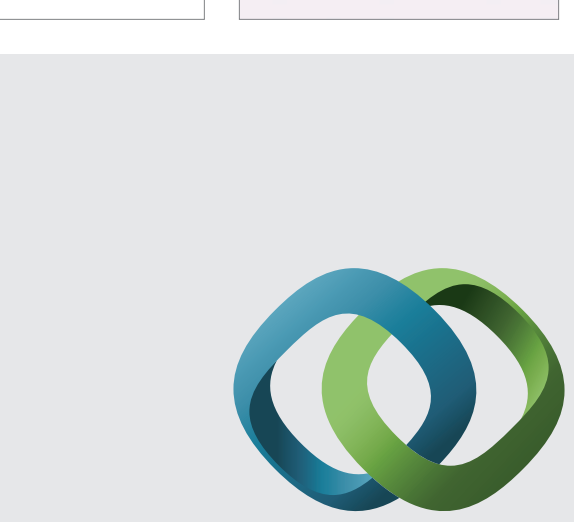

\section{Hindawi}

Submit your manuscripts at

http://www.hindawi.com
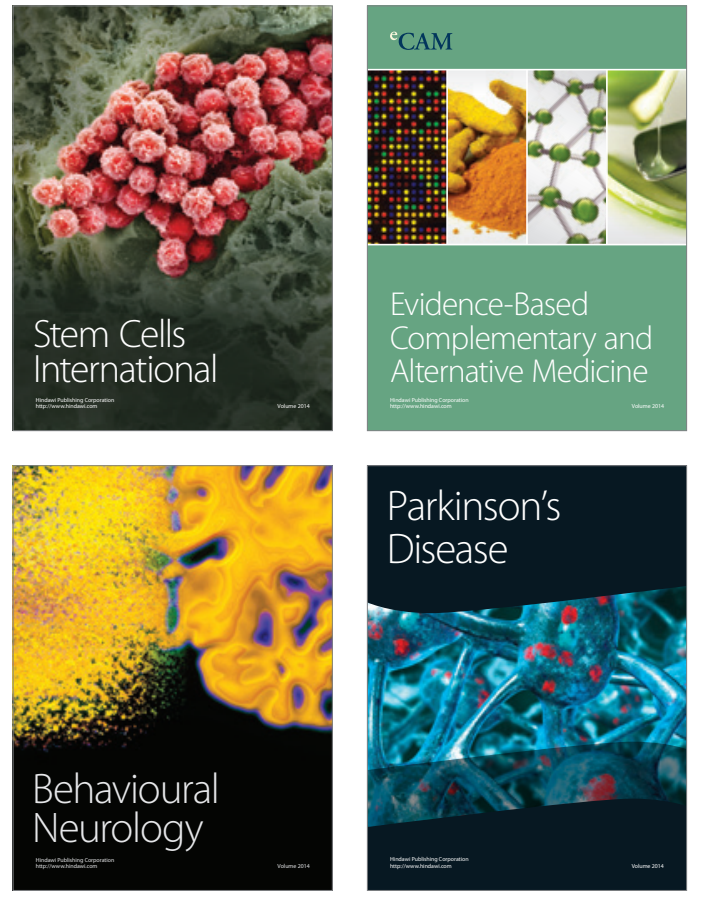
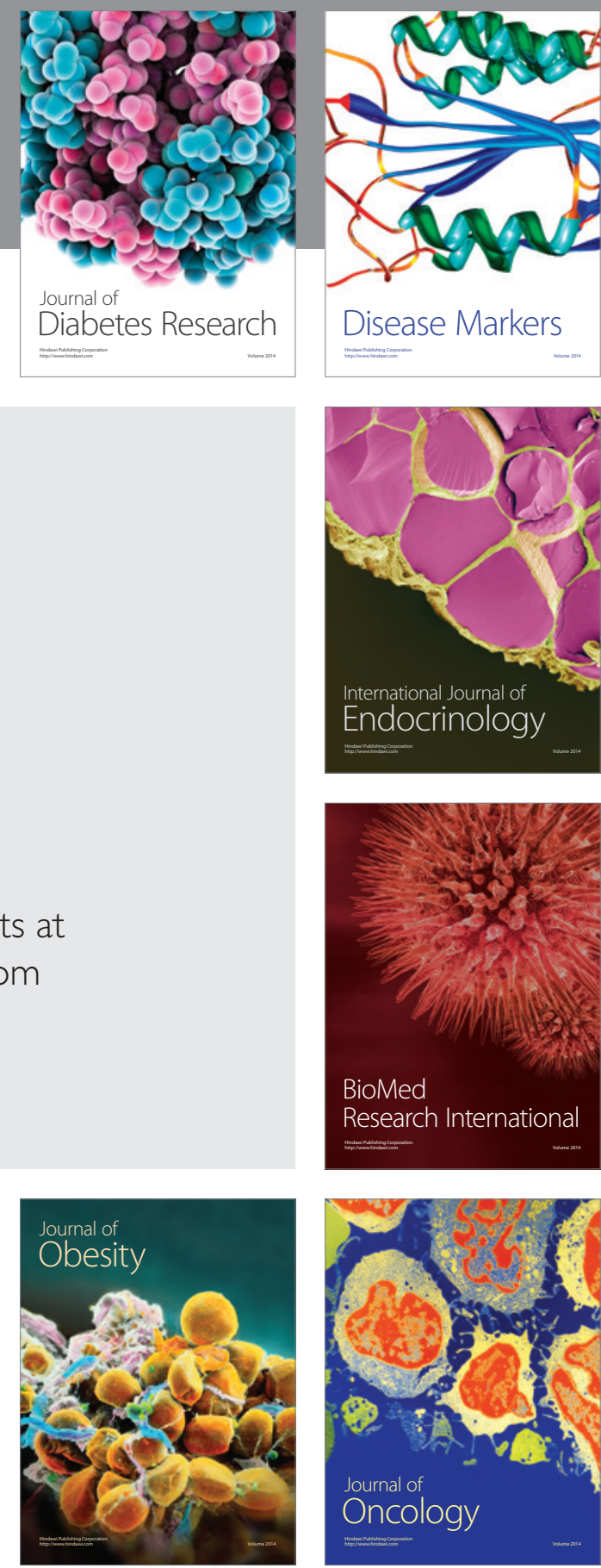

Disease Markers
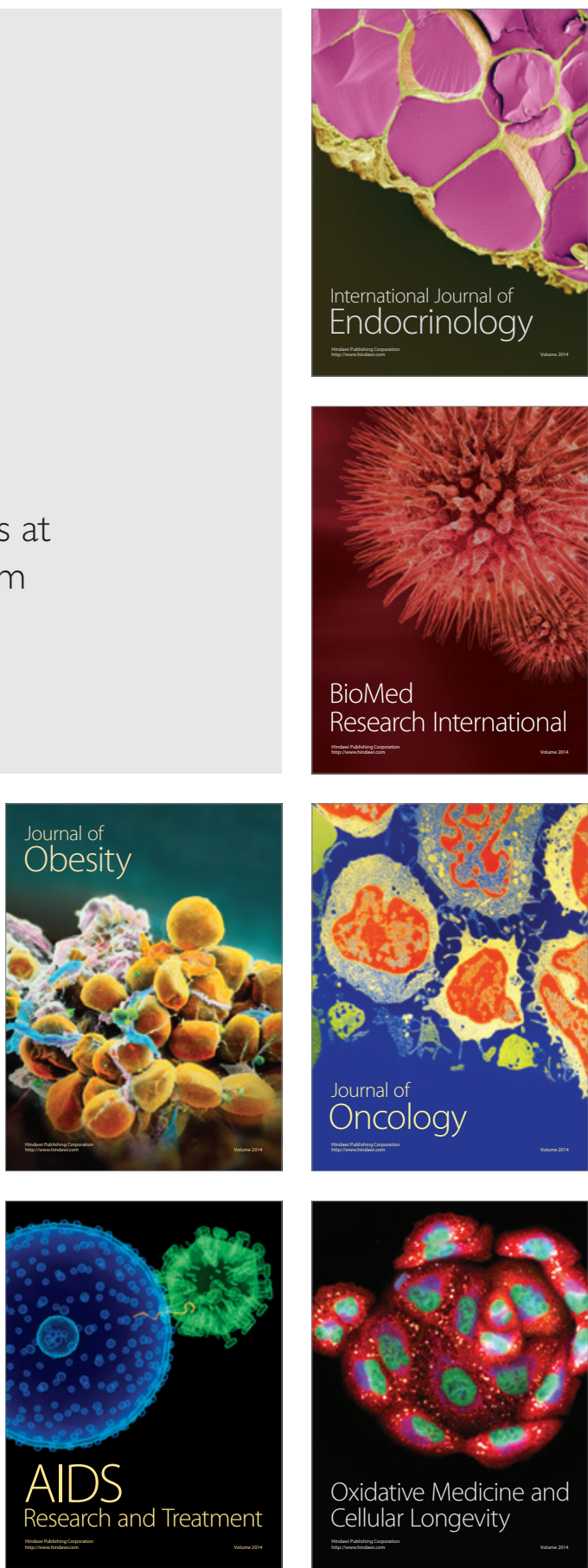